\title{
The origin of transparent exopolymer particles (TEP) and their role in the sedimentation of particulate matter
}

\author{
U. Passow*, R.F. Shipe, A. Murray ${ }^{1}$, D.K. Pak, M.A. Brzezinski, \\ A.L. Alldredge \\ Marine Science Institute, University of California, Santa Barbara, CA 93106, USA
}

Received 3 April 2000; accepted 11 July 2000

\begin{abstract}
Seasonal changes in the concentration of suspended transparent exopolymer particles (TEP) and flux rates of TEP and other particles at $500 \mathrm{~m}$ were measured at 2-week intervals at a station in the Santa Barbara Channel between May 1995 and June 1997 in order to investigate the hypothesis that the presence of TEP is necessary for the aggregation and subsequent sedimentation of particles from the pelagic zone. During the 2-year period phytoplankton appeared to be the most significant source of TEP. However, in association with phytoplankton, the concentration of TEP was also positively affected by bacteria abundance. Possibly bacteria enhance the production of TEP by phytoplankton. The presence of TEP was necessary for the sedimentation of diatoms. However, only $67 \%$ of the peaks in particulate organic carbon flux corresponded to peaks in TEP flux. Lithogenic silica sedimented only when scavenged by marine snow; either by TEP-rich diatom aggregates or by zooplankton-derived snow (larvacean houses). TEP were not involved in the sedimentation of foraminifera. Although sedimentation was the dominant loss processes of TEP out of the euphotic zone, other loss process must have been important at greater depth, as only a small fraction of the standing stock of TEP arrived at $500 \mathrm{~m}$. (C) 2001 Elsevier Science Ltd. All rights reserved.
\end{abstract}

Keywords: Sedimentation mechanisms; Marine snow; TEP; Transparent exopolymer particles; Particulate flux

\footnotetext{
*Corresponding author. Present address: Alfred-Wegener-Institute for Marine and Polar Research, D-27515, Bremerhaven, Germany.

E-mail address: upassow@awi-bremerhaven.de (U. Passow).

${ }^{1}$ Present address: Monterey Bay Aquarium Research Institute, 7700 Sandholdt Road, Moss Landing, CA 95039, USA.
} 


\section{Introduction}

The sedimentation of particles generated in the surface layer of the ocean is one of the main processes connecting the upper layer with the deep ocean and the benthos. The majority of particulate organic matter (POM) sinking to the sea-floor sediments as marine snow $(>0.5 \mathrm{~mm})$ at velocities of tens to hundreds of meters per day (Fowler and Knauer, 1986; Asper, 1987; Rice et al., 1994 and many others). Marine snow is produced from smaller particles by two major pathways: (1) zooplankton feeding which generates fecal pellets and large feeding structures, such as larvacean houses, and (2) aggregation, the process by which smaller particles like detritus, fecal matter, microorganisms and inorganic particles colloid and stick together to form larger, rapidly sinking aggregates (McCave, 1984; Fowler and Knauer, 1986; Alldredge and Silver, 1988). Although the vertical export of fecal pellets or feeding structures can be large at specific times and places (Taguchi, 1982; Morris et al., 1988) much of the POC exported from the surface ocean, both spatially and temporally, sinks as marine snow formed by the second pathway, aggregation (Silver and Gowing, 1991; Taylor and Karl, 1991).

The matrix of all marine snow aggregates examined to date, regardless of their origin and composition, consists of transparent exopolymer particles (TEP) (Alldredge et al., 1993, 1998; Passow et al., 1994). TEP are large, discrete, transparent particles (Alldredge et al., 1993) that form from polysaccharides released by microorganisms (Passow, 2000). The high abundance of TEP during many diatom blooms and in diatom cultures (Kiørboe and Hansen, 1993; Passow and Alldredge, 1994; Passow et al., 1994) suggests that diatoms release TEP-precursors abundantly. However, other phytoplankton species and bacteria are also known to release dissolved polysaccharides copiously (Decho, 1990) suggesting that other microorganisms may also be important for the production of TEP in marine systems.

The presence of TEP appears to be essential for the formation of diatom aggregates (Passow et al., 1994; Dam and Drapeau, 1995; Jackson, 1995; Logan et al., 1995), suggesting that TEP may facilitate the formation and subsequent sedimentation of fast sinking aggregates from particles too small to sink to great depth individually. Because the sinking velocity of unaggregated TEP is negligible (Alldredge et al., 1993), we propose that the presence of both TEP, which act as glue, and conventional particles, which provide weight, are required for the formation of sinking aggregates. In the absence of TEP, we expected, the export of carbon from surface waters to occur primarily through the zooplankton-grazing pathway, and the sinking material to be dominated by large fecal pellets or feeding webs and houses, not aggregates.

Thus we postulate that recently described TEP are central to understanding patterns of sedimentation and particulate flux in the ocean. This study was driven by two goals. First, we wanted to determine which organisms contribute primarily to the occurrence of TEP in situ. Second, we investigated whether the presence of TEP is essential for small particles to sediment. Data for this field study was collected over a 2-year period at a station in the Santa Barbara Channel, where we measured the concentrations of TEP and other particles in the euphotic zone and flux rates of TEP and other material at $500 \mathrm{~m}$. 


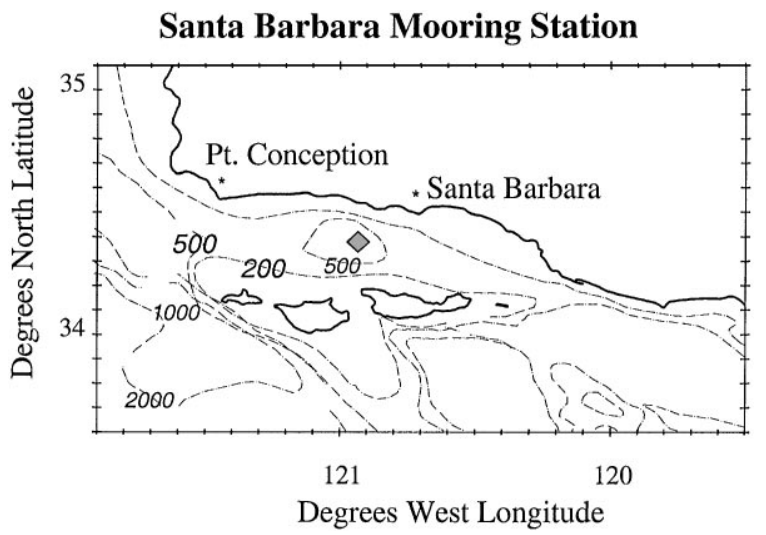

Fig. 1. Map of the Santa Barbara Channel, which is bordered by the coast line and the channel islands and the position of the SBM station.

\section{Methods}

\subsection{General description of the Santa Barbara Channel and circulation patterns}

The Santa Barbara Channel (SBC) is bound to the north by the south central Californian coast and to the south by 4 of the Channel Islands (Fig. 1). The channel has a general east-west orientation, is $100 \mathrm{~km}$ long and $40 \mathrm{~km}$ wide and the central basin is $>500 \mathrm{~m}$ deep. The overall circulation patterns are the result of interactions of wind stress and the pressure gradients across the channel due to temperature differences (Hendershott and Winant, 1996; Harms and Winant, 1998). If the wind stress overwhelms pressure gradients, then the mean flow in the channel is equatorward generating upwelling conditions. If the pressure gradient prevails, the overall flow in the channel is poleward, resulting in a relaxation period. When both wind stress and pressure gradient are large, a cyclonic eddy encompassing the entire basin is commonly encountered.

In spring and summer upwelling conditions dominate and freshly upwelled water from north of Point Conception is transported along the southern side of the channel. Superimposed on this flow pattern is frequently a large cyclonic eddy in the northern part of the SBC. In winter, wind stress and pressure gradients are commonly in the same direction and all the flow is either equator or pole-ward (Hendershott and Winant, 1996; Harms and Winant, 1998).

The Santa Barbara Mooring station (SBM-station, bottom depth $522 \mathrm{~m}$ ), which is located in the Santa Barbara Channel (34 $\left.15^{\prime} 04^{\prime \prime} \mathrm{N}, 119^{\circ} 54^{\prime} 66^{\prime \prime} \mathrm{W}\right)$, is positioned at the edge of the cyclonic eddy that brings in the phytoplankton-rich plume of water upwelled north off Point Conception. Because the station is located at the edge of the eddy short-term fluctuations are common and often reflect changes in the location of the eddy rather than temporal development within one water mass. Global weather patterns will impact flow patterns in the channel. During EL Nino conditions the probability of winter storms is increased in the Santa Barbara area and upwelling north of the channel is decreased. The sampling interval discussed in this paper was mildly influenced by weak El Nino conditions, which prevailed during winter 1994/95, and by strong El Nino conditions that started in summer 1997 and lasted until summer 1998. 


\subsection{Study site and field sampling}

The data for this study was collected between May 1995 and June 1997 at the SBM station. Seawater samples were collected to determine concentrations of TEP, Chl. $a$, POC, PON, biogenic silica $\left(\mathrm{bSiO}_{2}\right)$, lithogenic silica $\left(\mathrm{SiO}_{2}\right)$ and bacterial numbers within the upper $75 \mathrm{~m}$. Seawater samples were obtained from 6 depths $(0,10,20,30,50,75 \mathrm{~m})$ every 2 weeks with a Niskin bottle (101, General Oceanics). Seawater samples were stored insulated in the dark on board, and processed at our laboratory at the University of California, Santa Barbara, as soon as possible (usually within $2 \mathrm{~h}$ of collection). A Sea Bird Conductivity-Temperature-Depth system (SBE-19 CTD) was used to determine depth profiles of temperature, salinity, and density within the upper $100 \mathrm{~m}$. Zooplankton samples were collected in the upper $50 \mathrm{~m}$ with an oblique tow of a $333 \mu \mathrm{m}$ net ( $1 \mathrm{~m}$ diameter). Flux rates were measured with a funnel-shaped PARFLUX sediment trap deployed at a depth of $470 \mathrm{~m}, 50 \mathrm{~m}$ off the seabed. The trap sampled automatically at 14-day intervals and was recovered and redeployed every 6 months. Formalin in a salinity gradient was used as an in situ preservative (4\%, according to the JGOFS protocol).

\subsection{Analysis of suspended material}

\subsubsection{TEP determination}

TEP (transparent exopolymer particles) were analyzed colorimetrically (Passow and Alldredge, 1995b) from each depth. Six replicate samples of 50-300 ml each were filtered onto $0.4-\mu \mathrm{m}$ polycarbonate filters (Poretics) and stained with Alcian blue. Gum Xanthan was used as a calibration standard.

\subsubsection{Particulate organic carbon}

Total POC (particulate organic carbon) was determined on two replicate $500 \mathrm{ml}$ samples from each depth and analyzed according to Sharp (Sharp, 1991) on a Leeman Labs. Inc. CHN analyzer (CE Model 440).

\subsubsection{Chl. a}

For the determination of Chl. $a$ two replicate $20 \mathrm{ml}$ samples were filtered on $\mathrm{GF} / \mathrm{F}$ filters and analyzed following standard fluorometric methods (Parsons et al., 1984) using a Turner Model 111 fluorometer.

\subsubsection{Biogenic and lithogenic silica}

For particulate silica analyses, a volume of $500 \mathrm{ml}$ was filtered onto $0.6 \mu \mathrm{m}$ PC membrane filters (Poretics Co.) and filtration towers were rinsed with filtered seawater. Biogenic silica was digested using a $\mathrm{NaOH}$ technique and lithogenic silica was subsequently dissolved using a 2.5 mol solution of hydrofluoric acid (Brzezinski and Nelson, 1989). All silicic acid samples were measured using the acid-molybdate method (Strickland and Parsons, 1972) and modified to include a reagent blank (Brzezinski and Nelson, 1986), resulting in a detection limit of $50 \mathrm{nM}$. 


\subsubsection{Bacterial abundance}

Bacteria were only enumerated from 3 depths $(0,20$, and $75 \mathrm{~m})$ per station. Subsamples for bacterial abundance were preserved in glutaraldehyde ( $1 \%$ final concentration), stored at $4{ }^{\circ} \mathrm{C}$ and enumerated, usually within 1 week of collection. Standard methods employing DAPI staining and epifluorescence microscopy were used to enumerate the bacteria (Porter and Feig, 1980). In all cases, duplicate filters $(0.22 \mu \mathrm{m}$ black polycarbonate, Millipore) were prepared for each sample. Ten fields (averaging $>30$ cells/field; $3 \mathrm{ml}$ for surface and $20 \mathrm{~m}$ samples, and $5 \mathrm{ml}$ for $75 \mathrm{~m}$ samples) were counted per filter. The reported bacterial abundance was derived from the average of duplicate counts.

\subsubsection{Phytoplankton composition}

Species composition of dominant phytoplankton and appearance of TEP were identified microscopically from selected samples (days when Chl. $a$ peaked). Two samples were prepared for each of the upper 4 depths $(0,10,20,30 \mathrm{~m}$ ) by filtering 10-20 $\mathrm{ml}$ (slide 1) and 20-30 ml (slide 2), respectively. Filtered samples were stained for TEP and transferred to slides using the filter-freeze transfer technique (Passow and Alldredge, 1994). Slides were stored in slide boxes in sealed plastic bags (to prevent drying out) at room temperature and were later analyzed microscopically (magnification: 100 and 200).

\subsubsection{Zooplankton enumeration}

All zooplankton samples were preserved in Formalin (4\%) and later counted under a dissecting microscope (Wild). Only the distributions of zooplankton groups relevant for the production of marine snow are shown in this paper.

\subsection{Analysis of sedimented material}

Trap samples were processed following JGOFS-protocols. Recovered trap samples were split using a rotary splitter. One subsample $\left(\frac{1}{16}\right)$ each was used to determine silica (biogenic and lithogenic) and TEP concentrations. Another subsample was picked for swimmers using a dissecting scope and then sieved through a 1-mm mesh (Nitex). The dry weight of the fraction $>1 \mathrm{~mm}$ was determined using the entire $>1 \mathrm{~mm}$ fraction. The fraction $<1 \mathrm{~mm}$ was diluted to a total volume of $250 \mathrm{ml}$ with filtered seawater. Subsamples of this slurry were used for determination of POC, PON, carbonate and dry weight.

\subsubsection{Dry weight}

Dry weight was determined by filtering $10 \mathrm{ml}$ each on three replicate preweighed polycarbonate membrane filters $(0.4 \mu \mathrm{m})$ and reweighing samples on a Satorius microbalance after drying overnight at $60^{\circ} \mathrm{C}$.

\subsubsection{Particulate organic carbon and carbonate}

Total carbon $(\mathrm{TC}=\mathrm{POC}+$ carbonate) was determined on three replicate $10 \mathrm{ml}$ samples and analyzed on a Leeman Labs. Inc. CHN analyzer (CE Model 440). POC was determined the same way, except that before the measurements the filtered material was covered with $8 \mathrm{~N}$ hydrogen chloride using a dropper and promptly rinsed several times with filtered seawater. Carbonate 
concentration was determined by difference of the average TC and POC values (Knauer, 1991; Walsh et al., 1991).

\subsubsection{Silica}

Biogenic and lithogenic silica were each analyzed with two replicates as described in Shipe and Brzezinski (submitted). Briefly, one split $\left(\frac{1}{16}\right)$ of the trap samples was centrifuged in a preweighed $50-\mathrm{ml} \mathrm{PP}$ centrifuge tube at $1750 \mathrm{~g}$ for $10 \mathrm{~min}$. The clear supernatant was discarded and the procedure repeated. The sample was freeze-dried using a Labconco freeze-dry system and total dry weight determined. The biogenic silica content was determined using a time course digestion after the method of DeMaster (DeMaster, 1981) and dissolved silicon concentrations were then measured from $0.2 \mathrm{ml}$ of sample resulting in values of $6-15 \mu \mathrm{moll}^{-1}$. Lithogenic silica concentrations were determined by subtraction of the biogenic silica concentration from the total silica concentration. Total silica was determined by fusion of the biogenic silica in a platinum crucible with excess sodium carbonate to form sodium silicate that was analyzed colorimetrically (Shipe and Brzezinski, submitted).

\subsubsection{TEP}

This is the first time TEP was measured in sediment trap material, and the method for the determination of TEP in seawater (Passow and Alldredge, 1995b) had to be adapted for trap material. First we tested the effect of the trap fixative on phytoplankton with respect to the production of TEP. Concentration of TEP in treatment 1, consisting of fresh phytoplankton, was compared with that of treatment 2, where an aliquot of the fresh phytoplankton was mixed with a solution mimicking the trap fixative solution (Formalin in a salinity gradient). Concentrations of TEP were not different between treatments ( $3.5 \pm 0.5$ and $3.5 \pm 0.4 \mathrm{mg}$ Xan. eq., respectively), indicating that phytoplankton do not generate TEP when exposed to the fixative solution in traps.

Measurements of TEP in trap material may underestimate the concentration of TEP as high concentrations of lithogenic material can cover TEP and physically keep the dye from binding to the polysaccharides. Each trap sample was measured at three different concentrations in order to avoid underestimating TEP flux. Most samples were first diluted 1:10 and 1:20. Then, four replicates of $1 \mathrm{ml}$ each of the 1:10 dilution and four replicates of 1 and $1.5 \mathrm{ml}$ each of the 1:20 dilution were filtered onto $0.4 \mu \mathrm{m}$ polycarbonate filters and stained with Alcian blue as described in Passow and Alldredge (Passow and Alldredge, 1995b). Two additional filters of each of the three concentrations remained unstained. These unstained samples were used to measure absorption due to turbidity of sediments. Furthermore, six replicates of stained filters without samples were prepared (filter blanks) daily. Absorption of samples was corrected for filter blanks and for absorption due to turbidity. The corrected absorption was graphed against the amount of sample on the filter. This should give a straight line, with the slope representing the uncalibrated concentration of TEP in the diluted sample. When the interference of sediment in the diluted sample was too large, measurements were repeated using a higher dilution series. The concentration of TEP was also measured in the water used to dilute samples. This water, which was freshly filtered before use $(2 \times$ through $0.2 \mu \mathrm{m})$, had the same salinity as the trap sample. TEP concentration in this water was always below the limit of detection. 


\subsubsection{Microscopy of trap material}

Fecal pellets were enumerated from diluted (1:20) subsamples of the same split of trap samples used for TEP analysis. Samples were counted under an inverted microscope (Zeiss) at 10×. Euphausiid fecal strings were counted in their own group, all other pellets were counted in 2 size classes. Carbon content of pellets was estimated from volume assuming $69 \mu \mathrm{g}$ carbon $\mathrm{mm}^{-3}$ (Riebesell et al., 1995).

\subsection{Data processing}

\subsubsection{Stepwise multiple regression analysis}

In an attempt to explain variations in the concentration of TEP in the euphotic zone and in the flux of TEP at $500 \mathrm{~m}$ we used the statistics program S-plus 4 to build multiple regression models with TEP concentration and TEP flux as the response variables. Stepwise multiple regression analysis regresses in an exploratory manner a variable $Y$ (TEP concentration or TEP flux) on variables $X_{1}, X_{2}, X_{3}$, etc. These variables are combined to obtain a minimum of unexplained residual variance and the smallest number of independent variables by dropping any potential independent variables that do not remove a significant independent portion of the variance. The results of this procedure indicate relative importance of different variables in determining the concentration or flux of TEP. Candidate predictors ( $X$ variables) for the concentration of TEP in the water column included concentrations of Chl. $a$, POC, bSi, $1 \mathrm{Si}$, bacterial numbers, salinity, temperature and in situ fluorescence. The fluxes of $\mathrm{POC}, \mathrm{DW}, \mathrm{bSi}, \mathrm{Si}$ and carbonate were candidate predictors for the flux of TEP. In each case a stepwise linear regression function was used for the variable selection process to determine which parameters contributed significantly in explaining the response variable (TEP concentration or TEP flux). Residuals were analyzed to confirm that model assumptions were satisfied. The adequacy of the resulting models was determined by checking for outliers and influential observations. All variables were tested for autocorrelation and severe multicollinearity (correlation of independent variables with one another). Several iterations of these steps were conducted until an adequate model was found. We started with simple linear relationships and tried common transformations (e.g. log, square root, squared). To check for seasonality, we also separated the data into the upwelling and nonupwelling seasons and ran the models for each season separately.

\section{Results}

\subsection{Suspended matter}

\subsubsection{Integrated times series}

At the SBM-station seasonal changes were clearly visible in the temperature record at $20 \mathrm{~m}$ and in nutrient concentrations in the upper $20 \mathrm{~m}$ (Fig. 2a). During spring and early summer the water at the station was commonly dominated by water upwelled north of Point Conception, whereas in winter less productive conditions dominated. Here, we defined the "non-upwelling" period as the time interval when temperatures at $20 \mathrm{~m}$ depth were greater than $14^{\circ} \mathrm{C}$. This period coincided with overall low Chl. $a$ concentrations in the upper $75 \mathrm{~m}$. The non-upwelling period of 1995-96 started 


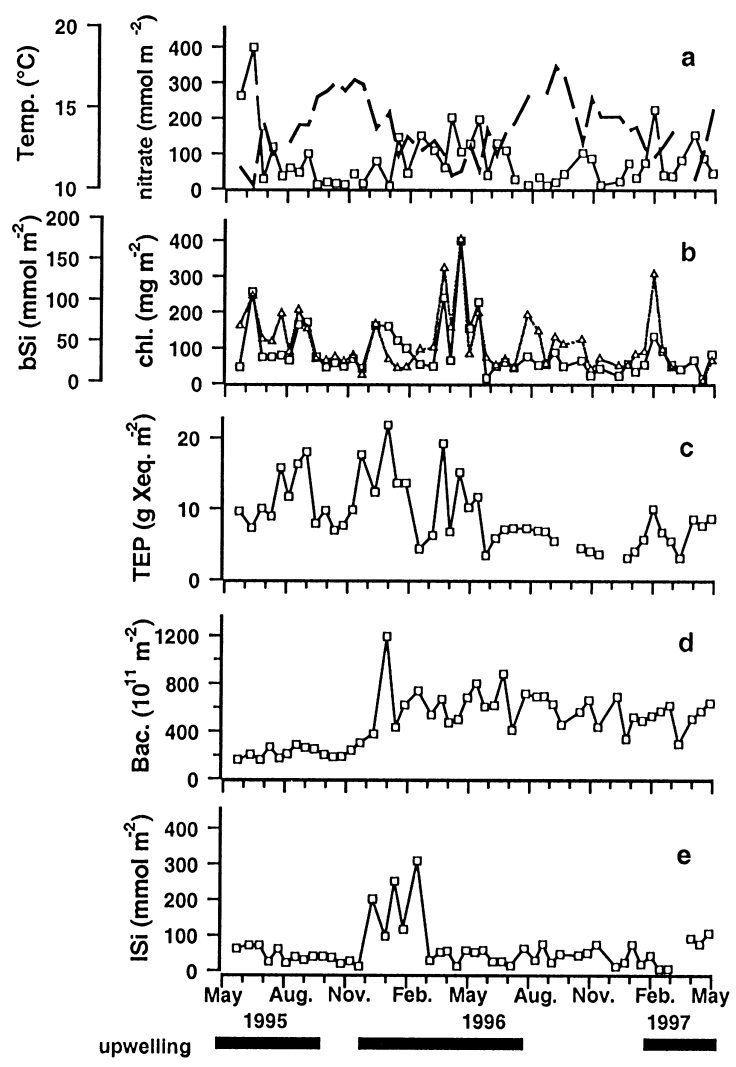

Fig. 2. Seasonal variability of water column properties during the 2-year study period: (a) temperature (dashed line) and nitrate concentration (solid line), (b) concentration of Chl. $a$ (solid line) and biogenic silica (dashed line), (c) concentration of TEP, (d) bacterial numbers and (e) concentration of lithogenic silica. Temperature data represents temperature at $20 \mathrm{~m}$, the nitrate data represents nitrate concentrations integrated between 0 and $20 \mathrm{~m}$ depth, all other data was integrated over the upper $75 \mathrm{~m}$. Integrated values were calculated assuming a linear change between sampled depths. Bars at the bottom of the graph mark the upwelling period as defined in the text.

in September $1995(9 / 15 / 95)$ and lasted only until December 1995, whereas the non-upwelling period of 1996-97 started already in July and ended in February 1997. During the two prior years (1993-94 and 1994-95) the non-upwelling periods had lasted from September to March, suggesting that compared to previous years the non-upwelling period ended 2-3 month earlier in winter of 1995-96 and started 1-2 month earlier in summer 1996. The "upwelling" period was characterized by low temperatures at a depth of $20 \mathrm{~m}$ (as low as $10-11^{\circ} \mathrm{C}$ ), by elevated nutrient concentrations at the surface and by large phytoplankton blooms (Figs. 2a and b).

During the 2-year study 7 bloom events with Chl. $a$ concentration peaking above $150 \mathrm{mg}$ Chl. $a \mathrm{~m}^{-2}$, (max. $399 \mathrm{mg}$ Chl. $a \mathrm{~m}^{-2}$ ) were observed on eight sampling dates (Fig. 2b). Four large blooms ( $>220 \mathrm{mg} \mathrm{Chl.} a \mathrm{~m}^{-2}$ ) that were observed during the central part of the upwelling seasons (one in 1995, three in 1996) and a smaller bloom during the first part of the upwelling season of 1997, were dominated by diatoms. Different species of Chaetoceros dominated the blooms 6/12/95 and 4/4/96, whereas more diverse diatom assemblages dominated $4 / 30 / 96$ and 5/28/96. Smaller, 
longer lasting blooms ( $>2$ weeks) at the end and the beginning of the upwelling periods of 1995 and 1996, respectively, were dominated by autotrophic dinoflagellates, but diatoms were abundant, especially initially.

All peaks in Chl. $a$ observed during the 2-year period, were associated with elevated concentrations in bSi $\left(>70 \mathrm{mmol} \mathrm{m}^{-2}\right)$, indicating the presence of diatoms (Fig. 2b). Additionally, integrated bSi was elevated 27 July 95, although Chl. $a$ concentration was only elevated at a depth of $20 \mathrm{~m}$ rather than in the upper $75 \mathrm{~m}$. High phaeopigment and POC concentrations indicate that a phytoplankton bloom in its declining phase was sampled on this date.

Overall, TEP concentrations in the upper $75 \mathrm{~m}$ followed Chl. $a$ concentrations, fluctuating between 3 and $22 \mathrm{mg} \mathrm{Xan.} \mathrm{eq} \mathrm{m}^{-2}$. Concentrations of TEP were elevated ( $>10 \mathrm{mg} \mathrm{Xan.} \mathrm{eq} \mathrm{m}^{-2}$ ) during 9 of the 10 phytoplankton blooms, with the bloom in June 95 as the only exception (Fig. 2c). In June 95 very web-like loose TEP was abundant $\left(500 \mu \mathrm{g}\right.$ Xan. eq. $\left.1^{-1}\right)$ at the surface where Chl. $a$ concentrations peaked $\left(22 \mu \mathrm{g}\right.$ Xan. eq. $\left.1^{-1}\right)$, but TEP concentrations were low below the surface. Because nitrate concentrations in the upper $20 \mathrm{~m}$ were extremely high (maximal value of the 2-year period: $399 \mathrm{mmol} \mathrm{m}^{-2}$ ), it may be assumed that the bloom was at the beginning of its growth phase, and formation of TEP may have just began. TEP concentrations above $15 \mathrm{~g}$ Xan. eq $\mathrm{m}^{-2}$ (up to $26 \mathrm{~g} \mathrm{Xan}$. eq $\mathrm{m}^{-2}$ ) were measured during three diatom blooms and during three mixed phytoplankton blooms. TEP concentrations above $10 \mathrm{~g} \mathrm{Xan.} \mathrm{eq} \mathrm{m}^{-2}$ were associated with a smaller diatom bloom and two mixed blooms. Once, in November 95, TEP concentrations peaked (Fig. 2c), although Chl. a concentration was not elevated.

Concentrations of bacteria integrated over the upper $75 \mathrm{~m}$, varied between 16 and $120 \times 10^{12}$ cells m$^{-2}$ and showed no regular seasonal pattern (Murray et al., 1999). None of the peaks in TEP concentration were associated with elevated bacteria concentrations, except during some phytoplankton blooms, where both bacteria and Chl. a concentrations peaked simultaneously (Fig. 2d). Peak concentrations of TEP were also not associated with any of the peaks in lithogenic silica, except once when maximum $1 \mathrm{Si}$ concentrations coincided with a phytoplankton bloom (Fig. 2e). Concentrations of lithogenic silica in the upper $75 \mathrm{~m}$ were fairly constant and low $\left(<70 \mathrm{mmol} \mathrm{m}^{-2}\right)$, except between late December 95 and March 96 when concentrations peaked above $200 \mathrm{mmol} \mathrm{m}^{-2}$ several times. This peak in 1Si in the euphotic zone must have been due to fluvial transport, as river discharge from the nearby Santa Clara River peaked between late December 95 and April 96 (Thunell, 1998).

\subsubsection{Regression analysis}

No evidence for autocorrelation was observed (95\% level) for the concentration of TEP, Chl. $a$ and POC, whereas autocorrelation could not be totally excluded for the concentration of 1Si and bSi (time lag of 4 weeks each). The lack of autocorrelation suggests, that the data did not represent a true time series, but that individual events were sampled. Scatter plots of TEP against POC, Chl. a, bSi, 1Si, bacterial numbers, temperature and salinity revealed weak linear relationships with POC, Chl. $a, \mathrm{bSi}, 1 \mathrm{Si}$ and bacterial numbers $(r=0.5$ to $0.6, p \ll 0.001$, $\mathrm{df}=260$ 270). TEP were not correlated $(r<0.4, p \ll 0.0001$, df $=250-260)$ with temperature or salinity.

Results of the stepwise linear regression models shown here, all assumed a simple linear relationship between TEP and predictors, as two-sided transformations did not result in better fits. One-sided transformations were not necessary as the data was reasonably normal distributed. Multicollinarity (correlation between predictors) was small $(r<0.35)$ except in four cases. POC 
correlated with Chl. $a$, bSi and bacterial numbers ( $r=0.73,0.63$ and 0.53 , respectively) and bSi correlated with Chl. $a(r=0.69)$. But concentration of bacteria, for example was not correlated with Chl. $a$ concentrations $(r=0.2, p<0.1, \mathrm{df}=28)$. Best model results were achieved when the data was divided into three different depth horizons: (1) the surface layer $(0 \mathrm{~m})$, (2) the phytoplankton-rich layer $(10-50 \mathrm{~m})$ and (3) the layer just below the euphotic zone (75 m). Results were also improved by separating data according to season. We describe results of the stepwise linear regression models for each of the three depth zones using data from the upwelling or the non-upwelling period, respectively.

3.1.2.1. Phytoplankton-rich layer. The model results suggested that during the upwelling period phytoplankton concentration (measured as bSi or Chl. a) could explain between 25 and $50 \%$ of the variability of TEP in the phytoplankton-rich layer $(10-50 \mathrm{~m})$. Adding bacterial abundance as a second predictor increased the value of the model appreciably at $20 \mathrm{~m} \mathrm{(} r^{2}$ increased from 25 to $51 \%, p \ll 0.0001, \mathrm{df}=26)$. Both predictors were positively correlated with TEP and individually significant ( $t$-test), suggesting that overall TEP was generated, rather than utilized by phytoplankton and bacteria. Because data on bacterial abundance was not available for the other depths of the phytoplankton-rich layer $(10,30,50 \mathrm{~m})$ bacterial abundance could not be offered as a predictor. In those cases the model selected bSi $(10 \mathrm{~m})$ or Chl. $a(20,30,50 \mathrm{~m})$ as the only predictor. More detailed model runs showed that the difference between bSi and Chl. $a$ as a predictor was negligible in all cases. None of the other potential predictors contributed to the variability in TEP in the phytoplankton-rich layer during the up-welling period. During the nonupwelling period no significant relationship was found between the concentration of TEP in the phytoplankton-rich layer and any of the potential predictors (always $p>0.2$ ).

3.1.2.2. The surface layer. The linear stepwise regression analysis suggested that during the upwelling period concentration of POC described the concentration of TEP in the surface layer best, accounting for $61 \%(p \ll 0.0001, \mathrm{df}=26)$ of the changes in TEP (Table 1). However, further analysis revealed that concentrations of TEP were described almost as well $(59 \%)$ by Chl. $a$ and bacteria abundance $(p \ll 0.0001$, $\mathrm{df}=24)$. During the non-upwelling period no significant relationship could be found between TEP concentrations at the surface and any of the potential predictors (always $p>0.05, \mathrm{df}=12$ ).

3.1.2.3. The layer below the euphotic zone. At a depth of $75 \mathrm{~m}$, concentrations of POC determined TEP concentrations best during the upwelling period $\left(r^{2}=16 \%, p<0.05, \mathrm{df}=27\right)$, but coefficients of determination and the level of significance were low. Adding $1 \mathrm{Si}$ as a second predictor improved

Table 1

Predictors for the concentration of TEP as selected by stepwise multiple regression modeling

\begin{tabular}{llll}
\hline & Surface layer & Phytoplankton-rich layer & Bottom layer \\
\hline Upwelling & POC (61\%), Or Chl. $a$ & Chl. $a$ or bSi & POC (16\%) Or POC \\
Non-upwelling & $\&$ Bacteria (59\%) & $\&$ Bacteria $(51 \%)^{\mathrm{a}}$ & $\& 1 \mathrm{Si}(21 \%)$ \\
\hline
\end{tabular}

${ }^{\text {a }}$ At $20 \mathrm{~m}$, values for the other depths in this layer were similar. 

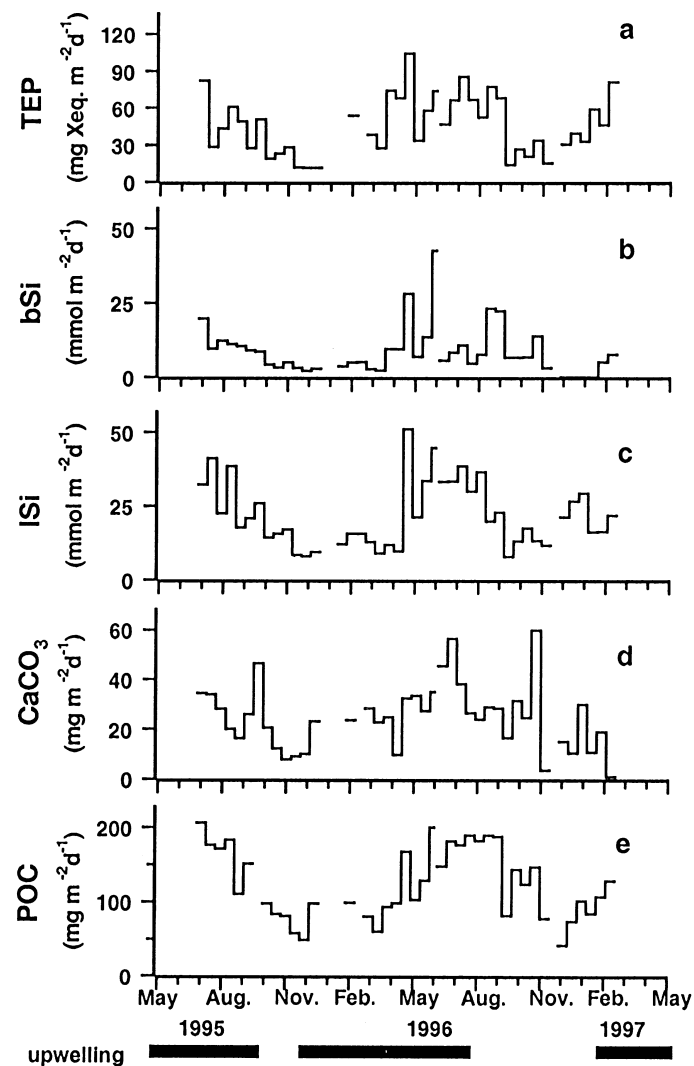

Fig. 3. Daily sedimentation rates of material at $500 \mathrm{~m}$ during each 2-week interval: Flux of (a) TEP, (b) biogenic silica, (c) lithogenic silica, (d) carbon in calcium carbonate and (e) particulate organic carbon. Data in January and February 96 is incomplete as traps overflowed and went anoxic. Bars at the bottom of the graph mark the upwelling period.

the model of the upwelling period only slightly $\left(r^{2}=21 \%, p<0.05, \mathrm{df}=26\right)$. None of the potential predictors could explain TEP concentration at $75 \mathrm{~m}$ during the non-upwelling period.

\subsection{Sedimented matter}

\subsubsection{Flux patterns}

Flux rates of dry weight (DW), POC, bSi and TEP were higher during the spring/summer months than in winter. Seasonality of flux rates mostly mirrored seasonality in the water column with a time lag of 2-4 weeks (Fig. 3), with high flux rates during the upwelling period. In spring and summer 1996 high flux rates lasted until September, 2 months longer than the upwelling period as defined from the water column data. Possibly upwelling events were missed by our twice monthly sampling scheme or sinking diatom blooms were brought into the area by lateral advection.

During the 2-year period, daily sedimentation rates of POC reflected sedimentation of DW, although POC contributed only $4-5 \%$ (maximum $7 \%$ ) to total dry weight. Because the flux of POC was closely correlated to that of DW $(r=0.94, p<0.0001, \mathrm{df}=38)$, only POC will be used in 
the following analysis. LSi contributed the largest fraction to total dry weight, 20-90\%. Both, direct fluvial input and resuspension probably contributed to elevated 1Si concentrations. Flux of 1Si varied between 8 and $50 \mathrm{mmol} \mathrm{m}^{-2} \mathrm{~d}^{-1}$ (Fig. 3c). Flux rates of $1 \mathrm{Si}$ peaked (6 peaks $>$ $30 \mathrm{mmol} \mathrm{m}^{-2} \mathrm{~d}^{-1}$ ) from July to August 1995 and 1996, as well as in association with two large sedimentation event of bSi in April and June 1996. Flux of bSi was low $\left(<10 \mathrm{mmol} \mathrm{m}^{-2} \mathrm{~d}^{-1}\right)$ and contributed only an average of $18 \%$ to DW except during several distinct sedimentation events. Flux rates of bSi reflected predominantly sedimentation of diatoms, as the bSi signal from sedimentation of radiolarians or silicoflagellates is small in the Santa Barbara Channel (Lange et al., 1997). High flux rates of bSi (> $20 \mathrm{mmol} \mathrm{m}^{-2} \mathrm{~d}^{-1}$ up to $43 \mathrm{mmol} \mathrm{m}^{-2} \mathrm{~d}^{-1}$ ) were observed July 1995 and in May, June, August and September 1996 (Fig. 3b). Carbonate carbon flux, which reflected mostly flux of foraminifera, contributed between 1 and $30 \%$ to flux of total carbon. Carbonate flux peaked $\left(>45 \mathrm{mg} \mathrm{m}^{-2} \mathrm{~d}^{-1}\right)$ in September/October 1995, in July 1996 and in November 1996 (Fig. 3d).

Sedimentation rates of TEP varied between 10 and $100 \mathrm{mg}$ Xan. eq $\mathrm{m}^{-2} \mathrm{~d}^{-1}$ during the 2-year investigation period and during the upwelling period TEP sedimentation rates regularly (20 times) exceeded $40 \mathrm{mg}$ Xan. eq $\mathrm{m}^{-2} \mathrm{~d}^{-1}$ (Fig. 3a). All peaks in the flux rates of bSi were associated with high flux rates of TEP. Although every sedimentation peak of bSi co-occurred with peak flux rates of TEP, the reverse was not true (Fig. 3a). Elevated flux rates of TEP were also associated with many, but not all of the peaks in POC flux (Fig. 3e). Four out of 6 times peak sedimentation of 1Si co-occurred with peak flux of TEP. High flux rates of $1 \mathrm{Si}$ were always associated with high POC fluxes. High flux rates of TEP were rarely associated with high fluxes of $\mathrm{CaCO}_{3}$ (Fig. 3d).

Daily sedimentation rate of TEP was equivalent to $<2 \%$ (mostly $<0.5 \%$ ) of standing stocks of TEP. Relative sedimentation rates of POC were equally low $(<3 \%)$, but between 15 and $50 \%$ of bSi standing stocks reached the trap daily. Daily sedimentation rates of 1Si ranged from 5 to $200 \%$. Relative sedimentation rates $>100 \%$ indicate a source of $1 \mathrm{Si}$ other than standing stocks in the upper $75 \mathrm{~m}$.

\subsubsection{Regression analysis of flux data}

The stepwise multiple regression analysis was run assuming linear relationships, as scatter plots suggested linear relationships between TEP and potential predictors. Model outputs suggested that the flux of TEP was best described by the flux of bSi plus that of 1Si. These two parameters explained $53 \%$ of the TEP flux during the 2-year period $(p<0.0001$, $\mathrm{df}=36)$. Separately the flux of $\mathrm{bSi}$ and $1 \mathrm{Si}$ each explained about $37 \%(p<0.00005$, $\mathrm{df}=38)$ of the TEP flux, confirming model results that both parameters were of similar importance in the model. The correlation between flux in TEP and bSi was stronger, if only data from the upwelling period was used. Multicollinarity between $\mathrm{bSi}$ and $1 \mathrm{Si}$ was small enough $(r=0.5$, $p<0.0005$, $\mathrm{df}=38$ ), not to effect our results adversely (rule of thumb test). The correlation between bSi and $1 \mathrm{Si}$ reflected the co-sedimentation of clays during sedimentation events of diatom blooms. Adding flux of DW or POC as a predictor did not improve model results. All analysis clearly showed that the flux of carbonate was not correlated with the flux of TEP. No evidence of autocorrelation (at the 95\% level) was observed for the flux of TEP, bSi, or carbonate, but some autocorrelation could not be excluded for the flux of 1Si (time lag of 1, 2 or 3 sampling intervals). 


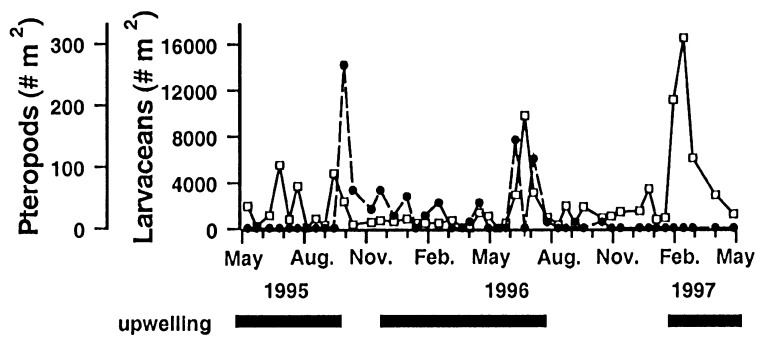

Fig. 4. Abundance of pteropods (dashed line) and larvaceans (solid line) in the water column.

Model runs with POC-flux as the response variable showed that TEP-flux was not a good predictor for POC-flux. DW, bSi and carbonate flux were the best predictors $(r=0.92, p \ll 0.0005$, $\mathrm{df}=36$ ) for POC-flux and even $1 \mathrm{Si}$ was a stronger predictor than TEP for POC-flux.

\subsection{Zooplankton-derived snow}

At the SBM station, zooplankton groups that may potentially contribute significantly to sinking matter include larvaceans (discarded houses) and web-feeding pteropods (discarded feeding webs or shells). Sinking material formed by larvaceans or pteropods was estimated from animal abundance data. Larvaceans can generate up to 6 houses per day (Fenaux, 1985), each of which contains about $5 \mu \mathrm{g}$ POC (Alldredge, 1998). At a concentration of 5000 animals m$^{-2}$, sinking old houses could contribute up to $150 \mathrm{mg} \mathrm{m}^{-2}$ POC. Concentrations of larvaceans reached values of $5000 \mathrm{~m}^{-2}$ or more during both summers and also in spring 1997 (Fig. 4). At these times larvaceans houses presumably contributed significantly to sinking marine snow.

Discarded pteropod feeding webs form mucus aggregates, which may contribute significantly to sinking matter (Bathmann et al., 1991). In feeding experiments 13-19 aggregates formed per animal per day, with a total aggregate volume of 4-5 $\mathrm{mm}^{3}$ animal $^{-1} \mathrm{~d}^{-1}$ (Noji et al., 1997). Using the volume to POC relationship of marine snow (Alldredge, 1998) the carbon content of these aggregates can be estimated as $2-2.2 \mu \mathrm{g}$ POC animal ${ }^{-1} \mathrm{~d}^{-1}$. However, concentrations of pteropods were low (Fig. 4), and even at their peak concentration the standing stock was only 265 animals $\mathrm{m}^{-2}$, so that aggregates formed from pteropod feeding webs could account for only $0.5 \mathrm{mg}$ POC m $\mathrm{m}^{-2} \mathrm{~d}^{-1}$ which was less than $1 \%$ of the daily POC sedimentation rate.

Pteropod shells may potentially also contribute to sinking matter. The calcium carbonate from pteropod shells weighs on average $0.008 \mathrm{mg}$ per shell (Fabry, 1988). However, because concentration of these animals was low, the standing stock could contribute at the most $2.1 \mathrm{mg}$ $\mathrm{CaCO}_{3}$ to sinking material (if all animals died simultaneously). This would contribute less than $3 \%$ to the average daily $\mathrm{CaCO}_{3}$ sedimentation rate.

The importance of fecal material for flux at $500 \mathrm{~m}$ was assessed from trap material. Euphausiid strings were most abundant between February and April 1996, with maximal sedimentation rates of $8 \times 10^{5}$ strings $\mathrm{m}^{-2} \mathrm{~d}^{-1}$ in April. Most fecal pellets (other than euphausiid strings) were relatively small $\left(<350 \mu \mathrm{m}\right.$ long) and ranged from 2 to $12 \times 10^{5}$ pellets $\mathrm{m}^{-2} \mathrm{~d}^{-1}$, with highest concentrations in August and September: $\left(8-12 \times 10^{5} \mathrm{~m}^{-2} \mathrm{~d}^{-1}\right)$ and low concentrations in spring $\left(<3 \times 10^{5} \mathrm{~m}^{-2} \mathrm{~d}^{-1}\right)$. On average, flux of fecal material at the SBM station contributed only $20 \%$ to POC, fluctuating between 10 and $30 \%$, and sinking feces never dominated flux. 


\section{Discussion}

\subsection{Data evaluation}

Small-scale heterogeneity at the SBM station was high because this station was positioned in a very dynamic environment, at the edge of an eddy. But general seasonal trends are the same everywhere in the California Bight and overall trends are representative. However, as sinking velocities of marine snow range between 50 and $100 \mathrm{md}^{-1}$ (Alldredge and Gotschalk, 1988), marine snow, which was formed at the surface, will arrive at 500 m-depth after 5-10 days, resulting in a decoupling between water column and trap data. Therefore we avoided a detailed comparison between data from the water column and the traps, although the flux of some blooms could be traced into traps at $500 \mathrm{~m}$ with a lag time of $1-2$ weeks.

\subsection{Sources of TEP}

Phytoplankton, bacterioplankton and terrigenous sources were investigated as potential sources of TEP. No indications were found that zooplankton generated appreciable amounts of TEP.

\subsubsection{Phytoplankton}

At the SBM station the concentration of TEP was high during each phytoplankton bloom and decreased thereafter, implying that phytoplankton was a primary source of TEP. TEP and phytoplankton also co-occurred during a 1-year study in a fresh water lake (Grossart and Simon, 1997). High TEP concentrations have been observed during many diatom blooms (Passow and Alldredge, 1994; Passow et al., 1994; Passow and Alldredge, 1995a; Grossart and Simon, 1997; Mari and Burd, 1998) and during blooms dominated by dinoflagellates (Alldredge et al., 1998; Berman, pers. comm. 1996), colony forming cyanobacteria (Grossart and Simon, 1997), Microcystis sp. (Worm and Sondergaard, 1998) and Phaeocystis (Passow and Wassmann, 1994; Riebesell et al., 1995; Hong et al., 1997) as well as in phytoplankton cultures (Kiørboe and Hansen, 1993; Passow and Alldredge, 1994; Waite et al., 1995).

The regression analyses confirm that in the phytoplankton-rich zone Chl. $a$ or bSi were the strongest predictors of TEP during the upwelling season. But since they only predict about $50 \%$ of the variability in TEP, phytoplankton biomass is a simple, but relatively poor predictor for TEP. The production rate of TEP depends on the physiological state of cells (Passow and Alldredge, 1995a) and on environmental conditions like available irradiance (Hong et al., 1997) and species composition (Passow and Alldredge, 1994) rather than on standing stocks, (Passow, submitted). At the surface phytoplankton was not the best predictor for TEP, possibly because phytoplankton was light stressed.

\subsubsection{Bacterioplankton}

During the upwelling season the concentration of TEP was best predicted by Chl. $a$ concentration and bacteria abundance. However, no association between bacteria and TEP existed during the non-upwelling period, although bacterial concentrations were comparable to 
those of the upwelling period, suggesting that bacteria did not impact TEP concentrations directly.

Although different interactions between TEP and bacteria have been postulated, the role of bacteria for the generation, preservation or destruction of TEP is still unclear. Like other extracellular polysaccharides TEP may be utilized by bacteria (Decho, 1990). Enzymatic degradation of TEP has been reported in a diatom bloom (Passow and Alldredge, 1995a; Smith et al., 1995). But because the relationship between TEP and bacteria was positive in our model, degradation of TEP by bacteria can be excluded as a dominating process in the surface ocean at the SBM station.

Although marine bacteria release extracellular polysaccharides ubiquitously (Decho, 1990) they do not appear to generate significant amounts of TEP (Schuster and Herndl, 1995). Our model is consistent with this hypothesis, as results imply that bacteria play an important role for the occurrence of TEP only when interacting with phytoplankton.

Possibly phytoplankton generate TEP more abundantly in the presence of bacteria. It has been hypothesized that diatoms release mucus to keep bacteria from attaching (Azam and Smith, 1991; Smith et al., 1995). High concentrations of bacteria would stimulate the production of TEP by phytoplankton. Bacteria may also contribute to the generation of TEP by enzymatic hydrolysis of diatom surface mucus (Smith et al., 1995). Bacterial activity has also been postulated to stabilize TEP (Schuster and Herndl, 1995).

\subsubsection{Terrigenous sources}

Concentration of TEP did not increase when fluvial input of $1 \mathrm{Si}$ (winter 1995/96) was high indicating that TEP was not associated with river run-off and that there were no significant terrestrial sources of TEP at the SBM station.

\subsubsection{Associations with POC and $l \mathrm{Si}$}

At $75 \mathrm{~m}$ depth concentrations of TEP were best predicted by POC and $1 \mathrm{Si}$. At this depth residual TEP probably existed predominantly attached to detrital organic and inorganic particles that sank slowly because particle concentrations were too low for them to aggregate at significant rates. As TEP are very sticky, they coat other particles readily (Passow et al., 1994; Logan et al., 1995).

\subsection{Is TEP driving flux of particulate matter?}

Although the importance of TEP for flux has been recognized (Alldredge et al., 1993; Logan et al., 1995; Schuster and Herndl, 1995), sedimentation rates of TEP have never been measured before. The potential importance of TEP for flux is two-fold. First, since TEP are large, sticky, and abundant they facilitate the aggregation of particles into larger, more rapidly sinking forms (Logan et al., 1995). Second, TEP themselves may contribute appreciably to sinking carbon, thus increasing carbon flux (Mari and Burd, 1998; Engel and Passow, 2000). We hypothesized that the presence of TEP is essential for the aggregation and subsequent sedimentation of small particles like phytoplankton or clays. Thus we expected peaks in flux of conventional particles to co-occur with high flux rates of TEP. Where peaks in flux were not related to TEP, we expected zooplankton-derived marine snow to dominate trap samples. 


\subsubsection{Sedimentation of phytoplankton}

At the SBM station every sedimentation event of bSi co-occurred with peak flux rates of TEP, suggesting that diatoms always sedimented in association with TEP. The simultaneous sedimentation of TEP and diatoms is also implied by data from a freshwater lake, where the sedimentation of a diatom bloom coincided with the disappearance of TEP from overlying waters (Logan et al., 1995; Grossart and Simon, 1997).

\subsubsection{Sedimentation of lithogenic silica}

Lithogenic silica at the SBM station was derived from direct fluvial input of terrestrial material in the winter and spring (Gorsline et al., 1984; Kolpack and Drake, 1984) and from material resuspended from the slopes of the basin by internal waves and tidally generated currents that forms a turbidity maximum between 100 and $300 \mathrm{~m}$ during all seasons (Washburn, unpublished). The flux of TEP and 1Si were correlated, suggesting that TEP-rich aggregates played an important role for the downward flux of mineral silica. Increased flux rates of 1Si in spring co-occurred with the sedimentation of diatom blooms, indicating that clay particles were scavenged by sinking diatom aggregates (e.g. spring 1996). The co-sedimentation of 1Si with phytoplankton has also been observed in the Sargasso Sea (Brzezinski and Nelson, 1995) and the Indian Ocean (Kumar et al., 1998). When high flux rates of $1 \mathrm{Si}$ at the SBM station did not cooccur with high sedimentation rates of TEP concentrations of larvaceans were high, suggesting that sinking larvacean snow scavenged lithogenic particles. High flux rates of $1 \mathrm{Si}$ were never observed in the absence of marine snow. Like phytoplankton cells these clay particles are too light to sink individually at significant speeds (Lick et al., 1993). High sedimentation rates of marine snow, either as TEP-rich aggregates or as zooplankton feeding webs were a prerequisite for high sedimentation rates of lithogenic particles. The co-sedimentation of large amounts of 1Si with marine snow, which is also the main vehicle for POC, explains the observed correlation of POC and DW.

\subsubsection{Sedimentation of foraminifera}

Sedimentation peaks of $\mathrm{CaCO}_{3}$ reflected predominately sedimentation of foraminifera as other carbonate containing organisms were rare (Pak, unpublished). High flux rates of foraminifera were never associated with sedimentation peaks of TEP, indicating that TEP are not associated with these organisms.

\subsubsection{Sedimentation of $P O C$}

Sedimentation of POC could not be predicted by TEP flux because the flux of POC at the SBM station included too many different categories of sinking particles. High sedimentation rates of foraminifera, larvacean houses or feces resulted in high flux rates of POC without causing peak flux rates in TEP. The large amount of sinking bSi further obscure the issue. Thus although, we could not disprove our hypothesis that TEP is necessary for the sedimentation of aggregates, TEP flux could not predict carbon flux at our station, due to the frequent occurrence of zooplanktonmediated marine snow. 


\subsection{Fate of TEP}

Only about half of the variability of flux in TEP could be explained by the flux of diatoms (bSi) and clays (1Si), indicating that other factors impact the sedimentation rate of TEP. TEP sediment via aggregates and as aggregation rates depend on the size distributions of all particles, sedimentation rates of TEP may differ appreciably between two hypothetical blooms exhibiting the same concentration of bSi and TEP. Furthermore, less than $2 \%$ of TEP were recovered at $500 \mathrm{~m}$, suggesting that loss processes other than sinking, including grazing (Dilling, 1997; Passow and Alldredge, 1999) and bacterial decomposition (Smith et al., 1992) must be important. Relative sedimentation rates of TEP at $500 \mathrm{~m}$ were comparable to those of POC suggesting that loss mechanisms were similar for both. Relative sedimentation rates of bSi were much higher.

\section{Acknowledgements}

We thank many people involved with the work at the SBM station, especially C. Gotschalk, C. Wyatt-Evans, M. Graham, S. Oakes and S. Adams for help with the data collection, S. Anderson and P. Von Langon for technical assistance, J. Kennett and E. Delong for providing the trap and funds, and E. Delong, L. Washburn and J. Warrick for the helpful discussions. The work was supported by the University of California, Santa Barbara, NOAA grant NA77RJ0453, the National Science Foundation grant OCE 952984 and a fellowship to U.P from the Deutsche Forschungsgemeinschaft.

\section{References}

Alldredge, A., 1998. The carbon, nitrogen, and mass content of marine snow as a function of aggregate size. Deep-Sea Research 45, 529.

Alldredge, A.L., Gotschalk, C., 1988. In situ settling behavior of marine snow. Limnology and Oceanography 33, 339351.

Alldredge, A.L., Silver, M.W., 1988. Characteristics, dynamics and significance of marine snow. Progress in Oceanography 20, 41-82.

Alldredge, A.L., Passow, U., Haddock, S.H.D., 1998. The characteristics and transparent exopolymer (TEP) content of marine snow formed from thecate dinoflagellates. Journal of Plankton Research 20, 393-406.

Alldredge, A.L., Passow, U., Logan, B.E., 1993. The abundance and significance of a class of large, transparent organic particles in the ocean. Deep-Sea Research I 40, 1131-1140.

Asper, V.L., 1987. Measuring the flux and sinking speed of marine snow aggregates. Deep-Sea Research 34, 1-17.

Azam, F., Smith, D.C., 1991. Bacterial influence on the variability in the oceans biochemical state: a mechanistic view. In: Demers, S. (Ed.), Particle Analysis in Oceanography. NATO ASI Series G 27, Springer, Berlin, pp. 213-233.

Bathmann, U.V., Noji, T.T., Von Bodungen, B., 1991. Sedimentation of pteropods in the Norwegian Sea in autumn. Deep-Sea Research Part A Oceanographic Research Papers 38, 1341-1360.

Brzezinski, M.A., Nelson, D.M., 1986. A solvent extraction method for the colorimetric determination of nanomolar concentrations of silicic acid in seawater. Marine Chemistry 19, 139-151.

Brzezinski, M.A., Nelson, D.M., 1989. Seasonal changes in the silicon cycle within a Gulf Stream warm-core ring. Deep-Sea Research 36, 1009-1030.

Brzezinski, M.A., Nelson, D.M., 1995. The annual silica cycle in the Sargasso Sea near Bermuda. Deep-Sea Research 42, 1215-1237. 
Dam, H.G., Drapeau, D.T., 1995. Coagulation efficiency, organic-matter glues, and the dynamics of particles during a phytoplankton bloom in a mesocosm study. Deep-Sea Research Part II Topical Studies in Oceanography $42,111-123$.

Decho, A.W., 1990. Microbial exopolymer secretions in ocean environments: Their role(s) in food web and marine processes. Oceanography and Marine Biology Annual Review 28, 73-153.

DeMaster, D., 1981. The supply and accumulation of silica in the marine environment. Geochimica et Cosmochimica Acta $45,1715-1732$.

Dilling, L., 1997. Consumption and fragmentation of marine snow by euphausiids and copepods. Ph.D. Thesis, University of California, Santa Barbara.

Engel, A., Passow, U., 2000. The carbon and nitrogen content of transparent exopolymer particles (TEP) derived from exudates of marine diatoms. Marine Ecology Progress Series, submitted.

Fabry, V., 1988. Aragonite production by pteropod molluscs: implications for the oceanic calcium carbonate cycle. Ph.D. Thesis, University of California, Santa Barbara.

Fenaux, R., 1985. Rhythm of secretion of oikopleurid's houses. Bulletin of Marine Science 37, 498-503.

Fowler, S.W., Knauer, D.A., 1986. The role of large particles in the transport of elements and organic components through the oceanic water column. Progress in Oceanography 16, 147-194.

Gorsline, D.S., Kolpack, R.L., Karl, H.A., Drake, D.E., Fleischer, P., Thornton, S.E., Schwalbach, J.R., Savrda, C.E. 1984. Studies of fine-grained sediment transport processes and products in the California Continental Borderland. In: Stow, D.A.V., Piper, J.W. (Ed.), Fine Grained Sediments: Deep Water Processes and Facies. The Geological Society, Blackwell Scientific Publications, Oxford.

Grossart, H.-P., Simon, M., 1997. Formation of macroscopic organic aggregates (lake snow) in a large lake: the significance of transparent exopolymer particles, phytoplankton, and zooplankton. Limnology and Oceanography $42,1651-1659$.

Harms, S., Winant, C.D., 1998. Characteristic patterns of the circulation in the Santa Barbara Channel. Journal Geophysical Research 103, 3041-3065.

Hendershott, M.C., Winant, C.D., 1996. Surface circulation in the Santa Barbara Channel. Oceanography 9, 114-121.

Hong, Y., Smith, W.O., White, A.-M., 1997. Studies on transparent exopolymer particles (TEP) produced in the Ross Sea (Antarctica) and by Phaeocystis antarctica (Prymnesiophyceae). Journal of Phycology 33, 368-376.

Jackson, G.A., 1995. TEP and coagulation during a mesocosm experiment. Deep-Sea Research II 42, 215-222.

Kiørboe, T., Hansen, J.L.S., 1993. Phytoplankton aggregate formation: observations of patterns and mechanisms of cell sticking and the significance of exopolymeric material. Journal of Plankton Research 15, 993-1018.

Knauer, G., 1991. Determination of mass flux, inorganic and organic mass flux in rapidly sinking particles. In: Hurd, D.C., Spencer, D.W. (Eds.), Marine Particles: Analysis and Characterization. American Geophysical Union, Washington D.C., pp. 79-83.

Kolpack, R.L., Drake, D.E., 1984. Transport of clays in the eastern part of the Santa Barbara Channel, California. Geo-Marine Letters 4, 191-196.

Kumar, M.D., Sarma, V.V.S.S., Ramaiah, N., Gauns, M., de Sousa, S.N., 1998. Biogeochemical significance of transparent exopolymer particles in the Indian Ocean. Geophysical Research Letters 25, 81-84.

Lange, C.B., Weinheimer, A.L., Reid, F.M.H., Thunnell, R.C., 1997. Sedimentation patterns of diatoms, radiolarians, and silicoflagellates in Santa Barbara Basin, California. CalCOFI Reports 38, 161-170.

Lick, W., Huang, H., Jepson, R., 1993. Flocculation of fine-grained sediments due to differential settling. Journal of Geophysical Research 98, 10,279-10,288.

Logan, B.E., Passow, U., Alldredge, A.L., Grossart, H.-P., Simon, M., 1995. Rapid formation and sedimentation of large aggregates is predictable from coagulation rates (half-lives) of transparent exopolymer particles (TEP). DeepSea Research Part II Topical Studies in Oceanography 42, 203-214.

Mari, X., Burd, A., 1998. Seasonal size spectra of transparent exopolymeric particles (TEP) in a coastal sea and comparison with those predicted using coagulation theory. Marine Ecology Progress Series 163, 63-76.

McCave, I.N., 1984. Size spectra and aggregation of suspended particles in the deep ocean. Deep-Sea Research I 31, $329-352$.

Morris, R.J., Bone, Q., Head, R., Braconnot, J.C., Nival, P., 1988. Role of salps in the flux of organic matter to the bottom of the Ligurian Sea. Marine Biology 97, 237-241. 
Murray, A.E., Blakis, A., Massana, R., Strawzewski, S., Passow, U., Alldredge, A.L., Delong, E.F., 1999. A time series assessment of planktonic archaeal variability in Santa Barbara Channel. Aquatic Microbial Ecology 20, 129-145.

Noji, T., Bathmann, U.V., von Bodungen, B., Voss, M., Antia, A., Krumbholz, M., Klein, B., Peeken, I., Noji, C.I.-M., Rey, F., 1997. Clearance of picoplankton-sized particles and formation of rapidly sinking aggregates by the pteropod, Limacina retroversa. Journal of Plankton Research 19, 863-875.

Parsons, T.R., Maita, Y., Lalli, C.M., 1984. A Manual for Chemical and biological Methods for Seawater Analysis. Pergamon Press, New York.

Passow, U., 2000. Formation of transparent exopolymer particles, TEP, from dissolved precursor material. Marine Ecology Progress Series 192, 1-11.

Passow, U. Production of TEP by phytoplankton and bacteria, submitted.

Passow, U., Alldredge, A.L., 1994. Distribution, size, and bacterial colonization of transparent exopolymer particles (TEP) in the ocean. Marine Ecology Progress Series 113, 185-198.

Passow, U., Alldredge, A.L., 1995a. Aggregation of a diatom bloom in a mesocosm: the role of transparent exopolymer particles (TEP). Deep-Sea Research II 42, 99-109.

Passow, U., Alldredge, A.L., 1995b. A dye-binding assay for the spectrophotometric measurement of transparent exopolymer particles (TEP). Limnology and Oceanography 40, 1326-1335.

Passow, U., Alldredge, A.L., 1999. Do transparent exopolymer particles (TEP) inhibit grazing by the euphausiid Euphausia pacifica? Journal of Plankton Research 21, 2203.

Passow, U., Alldredge, A.L., Logan, B.E., 1994. The role of particulate carbohydrate exudates in the flocculation of diatom blooms. Deep-Sea Research I 41, 335-357.

Passow, U., Wassmann, P., 1994. On the trophic fate of Phaeocystis pouchetii (Hariot): 4. The formation of marine snow by P. pouchetii. Marine Ecology Progress Series 104, 1-2.

Porter, K.G., Feig, Y.S., 1980. The use of DAPI for identifying and counting aquatic microflora. Limnology and Oceanography 25, 943-948.

Rice, A.L., Thurston, M.H., Bett, B.J., 1994. The IOSDL DEEPSEAS program: introduction and photographic evidence for the presence and absence of a seasonal input of phytodetritus at contrasting abyssal sites in the northeastern Atlantic. Deep-Sea Research I 41, 1305-1320.

Riebesell, U., Reigstad, M., Wassmann, P., Noji, T., Passow, U., 1995. On the trophic fate of Phaeocystis pouchetii (Hariot): VI. significance of Phaeocystis-derived mucus for vertical flux. Netherlands Journal of Sea Research 33, 193-203.

Schuster, S., Herndl, G.J., 1995. Formation and significance of transparent exopolymeric particles in the northern Adriatic Sea. Marine Ecology Progress Series 124, 227-236.

Sharp, J.H., 1991. Total mass of particulate carbon, nitrogen, and phosphorus. In: Hurd, D.C., Spencer, D.W. (Eds.), Marine Particles: Analysis and Characterization. American Geophysical Union, Washington D.C., pp. 87-91.

Shipe, R.F., Brzezinski, M.A., Silica production and flux in a non-upwelling eastern boundary region: Santa Barbara Basin, California. Global Biochemical Cycles, submitted.

Silver, M.W., Gowing, M.M., 1991. The particle flux and biological components. Progress in Oceanography 26, 75-113.

Smith, D.C., Meinhard, S., Alldredge, A.L., Azam, F., 1992. Intense hydrolytic enzyme activity on marine aggregates and implications for rapid particle dissolution. Nature 359, 139-141.

Smith, D.C., Steward, G.F., Long, R.A., Azam, F., 1995. Bacterial mediation of carbon fluxes during a diatom bloom in a mesocosm. Deep-Sea Research II 42, 75-97.

Strickland, J.D.H., Parsons, T.R., 1972. A Practical Handbook of Seawater Analysis, 2nd Edition, Ottawa, Canada, Fishery Research Board of Canada.

Taguchi, S., 1982. Sedimentation of newly produced particulate organic matter in a subtropical inlet, Kaneohe Bay, Hawaii. Estuarine, Coastal and Shelf Science 14, 533-544.

Taylor, G.T., Karl, D.M., 1991. Vertical fluxes of biogenic particles and associated biota in the eastern North Pacific: Implications for biogeochemical cycling and productivity. Global Biogeochemical Cycles 5, 289-303.

Thunell, R.C., 1998. Particle fluxes in a coastal upwelling zone: sediment trap results from Santa Barbara Basin, California. Deep Sea Research II 45, 1863-1884.

Waite, A.M., Olson, R.J., Dam, H.G., Passow, U., 1995. Sugar-containing compounds on the cell surfaces of marine diatoms measured using concanavalin A and flow cytometry. Journal of Phycology 31, 925-933. 
Walsh, T.W., Smith, S.V., Vink, S., 1991. Review of particulate C, N and P services at UH/HIMB. In: Hurd, D.C., Spencer, D.W. (Eds.), Marine Particles: Analysis and Characterization. American Geophysical Union, Washington D.C., pp. 91-96.

Worm, J., Sondergaard, M., 1998. Dynamics of heterotrophic bacteria attached to Microcystis spp. (Cyanobacteria). Aquatic Microbial Ecology 14, 19-28. 